\title{
The Impact of Entrepreneurship Education on Students Entrepreneurial Intentions and Opportunity Identification Perceptions
}

Saeid Karimi*, Harm J.A. Biemans, Thomas Lans, Martin Mulder, and Mohammad Chizari

*saeid.karimi@wur.nl

Department of Social Sciences, Education and Competence Studies Group, Wageningen University, Wageningen, the Netherlands

\begin{abstract}
This study, based on the Theory of Planned Behaviour (TPB), assesses the impact of entrepreneurship education programs (EEPs) on entrepreneurial intentions of 205 students following entrepreneurship courses at six Iranian universities. Data were collected by a questionnaire before and after completing EEPs. Result indicated that EEPs significantly influence perceived behavioral control and subjective norms. However, no support was found for the effects of EEPs on attitudes toward entrepreneurship, opportunity identification, and intention. Findings suggest that the TPB could be considered to provide a useful framework to analyze how EEP might influence students' entrepreneurial attitudes and intentions.
\end{abstract}

Keywords: Entrepreneurship Education, Entrepreneurial Intention, Opportunity Identification, Theory of Planned Behaviour, Iran 


\section{Introduction}

Entrepreneurial education is a fast growing area and hot topic in colleges and universities all around world and its supposed benefits have been much praised by researchers and educators; nevertheless, the outcomes and effectiveness of entrepreneurship education programs (EEPs) has remained largely untested (Pittaway \& Cope, 2007; von Graevenitz et al., 2010). According to Alberti et al. (2004) the first and the most important area for further investigation should lie in assessing the effectiveness of these programs. However, there is an important question that needs to be answered: how should entrepreneurship education be assessed. One of the most common ways to evaluate an entrepreneurship education program is to assess individuals' intentions to start up a new business. Intentionality is central to the process of entrepreneurship (Bird, 1988; Krueger, 1993) and the studies show that entrepreneurial intentions (EI) are a strong predictor of entrepreneurial behavior. Nonetheless, the impact of EEPs on EI to set up a business is poorly understood at present and it has remained relatively untested (Kruegel and Brazeal, 1994; Souitaris et al. 2007; Peterman and and Kennedy, 2003; Athayde, 2009; von Graevenitz et al., 2010). The Theory of Planned Behaviour (TPB) is very well applicable to evaluating EEPs (Weber, 2012) and it has been empirically used to assess the impact of EEPs on the El of the students by some researchers and successfully proven its strength (Fayolle and Gailly, 2006; Souitaris et al., 2007). As such, it is considered as providing a useful framework to analyze how EEPs might influence students regarding their El. Moreover, developing opportunity identification abilities is a key element of entrepreneurship process that EEPs should enhance this competency and act upon it (Linan et al., 2011; Kourilsky, 1995). However, there is by now little empirical studies regarding the effects of education on this competency (Nixdorf and Solomon, 2007; Alsos and Kaikkonen, 2004).

In the present study, therefore, the effects of EEPs on two first important elements of entrepreneurship process, i.e., entrepreneurial intention and ability to identify opportunity business are assessed. We suggest that if EEPs prim students to perceive entrepreneurship desirable and feasible, and if these programs help students to believe in their ability to identify new business opportunities and start up a business, then they are more likely to start their own business.

\section{Literature Review and Hypotheses}

In social psychology literature, intentions have proved to be a strong predictor of planned individual behaviors, especially when that the behavior is rare, difficult to observe, or involves unpredictable time lags (Krueger, Reilly and Carsrud, 2000); entrepreneurship is a typical example of such planned and intentional behavior (Bird, 1988; Krueger and Brazeal, 1994).

There is a vast body of literature arguing that intentions play a very pertinent role in the decision to start a new business (Linan and Chen, 2009). As a consequence, during the last recent years, employment status choice models that focus on entrepreneurial intention have been the subject of considerable interest in entrepreneurship research (Krueger and Carsrud, 1993; Kolvereid, 1996).

In these models career intention is seen as the immediate antecedent of behavior (such as starting a business). Intentions in turn are determined by attitudes, and attitudes are affected by 'exogenous influences' such as traits, education, demographics and situational variables (Ajzen, 1991; Kolvereid, 1996; Krueger, 2003; Segal, Borgia \& Schoenfeld, 2005; Souitaris et al., 2007). Among intention models, one of the most widely researched is Theory of Planned Behavior (TPB) (Ajzen, 1988, 1991). The efficacy and ability of TPB to predict entrepreneurial intentions has been proven by number of studies in entrepreneurship (e.g. Kolvereid, 1996; Krueger et al., Autio et al., 2001; Engle et al., 2010; Karimi et al., 2012, 2013).

In order to assess the effect of EEPs, the present study follows Fayolle et al, (2006) and Souitaris et al. (2007) to incorporate EEPs as an exogenous influence into the TPB. In addition, 
this study develops and extends the TPB model by incorporating the perception of opportunity identification as a proximal cause of entrepreneurial intention, and it examines the relationship between this variable and $\mathrm{El}$ and its antecedents.

The central factor of the theory is the individual intention to perform a given behavior. Consequently, the model stresses that three key attitudes or independent antecedents predict intention: attitudes toward the behavior (the degree to which the individual holds a positive or negative personal valuation about being an entrepreneur (Autio et al., 2001; Kolvereid, 1996b), subjective norms (the perceived social pressure from family, friends or significant others (Ajzen, 1991) to start a new business or not), and perceived behavioral control (the perceived easiness or difficulty of becoming an entrepreneur). The theory predicts that the greater the favorable attitude and subjective norm with respect to the behavior, combined with a strong perceived behavioral control, the greater the intention will be to perform the particular behavior. This theory has been applied for the prediction of a wide range of human behaviors (Fayolle et al. 2006) including entrepreneurial intentions.

Krueger and Carsrud (1993) were the first to apply the TPB in the specific context of entrepreneurship education. They pointed out that an education program can have an impact on the antecedents of intention identified by the TPB. Fayolle et al. (2006) found that entrepreneurship education has a strong and measurable effect on the El of students, while it has a positive, but not very significant, impact on their perceived behavioral control (PBC).

Souitaris et al. (2007) used the TPB in order to test the impact of EEPs on attitudes and intention of science and engineering students. They found that EEPs significantly increased students' El and subjective norms. However, they did not find a significant relationship between entrepreneurship education and attitudes and PBC. Whereas Peterman and Kennedy (2003) and Athayde (2009) found a positive effect of EEPs on intention and perceived feasibility or attitude of high-school students. Dohse and Walter (2010) reported that EEPs were positively related only to attitude, but not subjective norms and PBC.

Overall, we can conclude that results about entrepreneurship education initiatives are somewhat inconclusive, and that more detailed research is needed to get a full understanding of the link between entrepreneurship education and attitudes-intentions

According to entrepreneurship education literature, opportunity identification could and should be taught and it should be a central topic in programs that aim to train future entrepreneurs (Sacks and Gaglio, 2002). In the same path, DeTienne and Chandler (2004) state that the entrepreneurship classroom is an appropriate place for fostering the skills required to enhance opportunity identification competencies. The results of study done by them indicated that EEPs led to the identification of more opportunities and more innovative opportunities. Munoz and et al. (2011) also reported that EEPs develop students' opportunity identification capabilities. Moreover, some studies show that EEPs can increase entrepreneurial knowledge of students (McNally et al. 2010) and it has been proven that there is a positive relationship between entrepreneurial knowledge and identification of entrepreneurial opportunities (Shepherd \& DeTienne, 2005).

Hypothesis1: Students that have followed an EEP will have higher (a) attitude towards entrepreneurial behavior, (b) subjective norm about entrepreneurship, (c) perceived behavioral control and (d) entrepreneurial intentions after the program than before the program.

Hypothesis2: Students who have followed an EEP the more likely they will be able to identify opportunities for new businesses after the program than before the program

\section{Research Method}

During the 2010-2011 academic year, an ex-ante and ex post survey was used to measure the change in students entrepreneurial intentions and opportunity identification over approximately a 4-month period in entrepreneurship courses at six Iranian universities. Our research used a 
quantitative method, including a questionnaire that was handed out at the beginning of the first session (T1) and at the end of the final session (T2) of the courses.

The measure of attitude, PBC, and intention were adopted from Linan and Chen (2009). For subjective norms, we adopted a measure developed by Kolvereid (1996). The perception of opportunity identification competence was measured through eight items selected from the literature on opportunity identification, gauging both the self-perceived ability to recognize opportunities and alertness to opportunities when they exist.

Undergraduate students who enrolled in entrepreneurship courses at the selected universities served as the sample for the study $(n=320)$. The reason for including a high number of different universities was the objective of covering a wide range of different class characteristics and of different ranking of Iranian universities. As not all the students in the university were allowed to take entrepreneurship courses, respondents for our questionnaire were selected on a purposive basis. In the first survey, 275 students participated and in the second survey, 240 students. For 205 students we were able to match the questionnaires (at t1 and at t2). They represent 64 percent of total enrollment in the entrepreneurship courses at the selected universities. A t-test indicated non-significant differences between respondents and "incomplete" non-respondents (students who filled in the t1-questionnaire but failed to respond at t2).

The sample was 205 university students, 86 men (\%42) and 119 women (\%58), with ages ranging between 19 and 31, and a mean 22.08 years. There was no control groups, just participating students filled out both questionnaires.

In general terms, the distribution of the sample according to college major includes: Agricultural Sciences (49.8\%), Engineering Sciences (21.5\%), and Business Science (21.5\%), other majors (Humanistic and Basic Sciences) (7.2\%),

At the general level, we measured the central TPB constructs with a multi-item measure based on the work of previous authors. The responses were given on a 7-point scale ranging from 1 (I totally disagree) to 7 (I totally agree). These items, the sources from where the items were adapted and their reliabilities are summarized in Table 1.

Table 1: Details of the constructs

\begin{tabular}{|l|l|l|l|l|}
\hline Construct & Literature Source & \multicolumn{2}{l|}{$\begin{array}{l}\text { No } \\
\text { of } \\
\text { Item }\end{array}$} & \multicolumn{2}{l|}{$\begin{array}{l}\text { Cronbach's } \\
\text { alpha }\end{array}$} \\
\cline { 3 - 5 } & & \multicolumn{1}{l|}{ T1 } & T2 \\
\hline $\begin{array}{l}\text { Entrepreneurial } \\
\text { Intentions }\end{array}$ & $\begin{array}{l}\text { Liñán and Chen (2009); e.g., "I'm ready to make } \\
\text { anything to be an entrepreneur". }\end{array}$ & 6 & 0.84 & 0.85 \\
\hline $\begin{array}{l}\text { Attitude toward } \\
\text { Entrepreneurship }\end{array}$ & $\begin{array}{l}\text { Linan and Chen (2009); e.g., "A career as an } \\
\text { entrepreneur is totally unattractive to me". }\end{array}$ & 5 & 0.82 & 0.91 \\
\hline $\begin{array}{l}\text { Subjective Norm } \\
\text { (belief and motivation } \\
\text { to comply) }\end{array}$ & $\begin{array}{l}\text { Adapted from Kolvereid (1996b), which has been } \\
\text { used in Kolvereid and Isakson (2006); Krueger et } \\
\text { al. (2000) and Souitaris et al. (2007): } \\
\text { - Closest family (belief*recoded motivation) } \\
\text { - Closest friends (belief*recoded motivation) } \\
\text {-Important others (belief*recoded motivation) }\end{array}$ & 6 & 0.78 & 0.85 \\
\hline $\begin{array}{l}\text { Perceived } \\
\text { behavioural control }\end{array}$ & $\begin{array}{l}\text { Linan and Chen (2009); e.g., "Starting a firm and } \\
\text { keeping it viable would be easy for me" }\end{array}$ & 6 & 0.82 & 0.91 \\
\hline $\begin{array}{l}\text { Opportunity } \\
\text { identification } \\
\text { perception }\end{array}$ & $\begin{array}{l}\text { Adapted from the literature (e.g., Ozgen and } \\
\text { Baron 2007; Singh et al. 1999; Hills 1995; Hills et } \\
\text { al. 1997; McCline et al. 2000; Ucbasaran and } \\
\text { Westhead 2003; Nicolaou et al. 2009); e.g., "I } \\
\text { have a special alertness or sensitivity toward } \\
\text { business opportunities in my environment." }\end{array}$ & 8 & 0.83 & 0.81 \\
\hline
\end{tabular}


The statistical analysis was made in two parts: first, Structural Equation Modelling (SEM) using Amos 18.0 was employed to define the relationship between El and its antecedents and to test the relationships between PBC, opportunity identification competency, and intention. Second, to test the impacts of EEPs on the students' entrepreneurial attitudes, opportunity identification competency, and intentions, paired t-test was used.

\section{Results}

The results revealed that at both pre-test and post-test time, students' El was significantly influenced by attitudes toward entrepreneurship, subjective norms, and PBC. This confirms the validity of the TPB in this study.

Table 2 summarizes the results of repeated measurement analysis. The results showed positive and significant differences in pre- and post-values of subjective norms and PBC, confirming Hypotheses $2 b$ and $2 c$.

The significant increase in PBC shows that EEPs have successfully increased the students' confidence in their abilities to start, control, and manage their own business. A possible explanation for this result can be related to the fact that most EEPs try to emphasis on the "leaning-by-doing" component and to expose the students to a real world. According to social learning theory (Bandura 1977, 1982), mastery experience is the most powerful factor in fostering individual's self-efficacy or PBC. The significant increase in mean of subjective norms may reflect the emphasis of EEPs on teamwork and the creation of a new circle of entrepreneurial-minded friends from EEPs.

The results also indicated that although the post-test values of attitudes toward entrepreneurship, opportunity identification, and El were increased compared to the pre-test ones, however, these increases were not very significant. Thus, hypotheses $1 \mathrm{a}, 1 \mathrm{~d}$, and 2 were not supported.

A possible explanation for our findings is that the students had relatively high attitude and intention at the beginning of the program and therefore there was less scope for changing their attitudes and intention. With respect to opportunity identification, one explanation for this result can be related to the fact that despite the emphasis of EEPs on opportunity identification, most teachers did not pay the necessary attention to fostering this competency in their classes. The results of interviews with some students and teachers after the post-test measurement indicated that this competency was often ignored or received less emphasis during the courses.

Table 2: Results of paired t-test for the programs' impacts $(N=205)$

\begin{tabular}{lllllll}
\hline \multirow{2}{*}{ Scale } & \multicolumn{2}{c}{ Pre-test } & \multicolumn{2}{c}{ Post-test } & \multicolumn{2}{c}{ Difference } \\
\cline { 2 - 7 } & $\boldsymbol{M}$ & $\boldsymbol{S D}$ & $\boldsymbol{M}$ & $\boldsymbol{S D}$ & $\boldsymbol{t}(\mathbf{2 0 4})$ & $\boldsymbol{p}$ \\
\hline Entrepreneurial Intention & 4.85 & 1.43 & 5.06 & 1.32 & 1.83 & 0.068 \\
Subjective Norms & 2.25 & 5.67 & 4.08 & 7.07 & 3.28 & $0.001^{* *}$ \\
Attitude toward Entrepreneurship & 5.13 & 0.95 & 5.22 & 1.04 & 0.904 & 0.367 \\
PBC & 4.35 & 1.32 & 4.68 & 1.28 & 2.92 & $.004^{\star *}$ \\
Opportunity Identification Perception & 4.31 & 1.15 & 4.38 & 0.97 & 0.752 & 0.453 \\
\hline$* * P<0.01,{ }^{*} P<0.05$ & & & & & &
\end{tabular}

With respect to opportunity identification, an explanation for this result can be related to the fact that despite the emphasis of EEPs on opportunity identification, some teachers did not pay the needed attention to fostering this competency in their classes. The results of interviews with some students and teachers in post-test time indicated that this competency was often ignored or less emphasized.

The results of correlation analysis revealed that a change in attitude, subjective norms, PBC, and opportunity identification perception was significantly related to an increased intention to 
start one's own business. In other words, students who had increased their attitude, their subjective norms, their PBC, and their opportunity identification perception had also increased their intention to start their own business.

\section{Implications}

Practically, the study provides valuable information and insight for those who formulate, deliver and evaluate educational programs to increase the entrepreneurial intention of students. Our findings strongly suggest that participation in entrepreneurship education programs can positively influence students' subjective norms and PBC, conforming that universities can shape and foster entrepreneurial abilities and subjective norms through EEPs.

\section{Limitations}

The current study has several limitations that provide future research opportunities. We did not have control groups to compare with our treatment groups; therefore, we are unable to determine the exact impact of EEPs on students' El. Although we can assume that these significant pre-test post-test differences are the results of participating in EEPs because the contents of EEPs are very specific and not duplicated in other courses, however, the availability of a control group would have strengthened our findings. Reliance solely on self-report measures presents another limitation. Future research should include what other than selfreports to assess the impact of EEPs on El and its predictors. Finally, future research should focus on the intention-behavior relationship. This link has been studied even less than the one between antecedent attitudes and El. Therefore, the longitudinal study is recommended for future research, as it can capture the changes of entrepreneurial attitudes and intention over time and the subsequent formation of entrepreneurial behavior from intention.

\section{References}

Alberti, A., Sciascia, B., \& Poli. (2004). Entrepreneurship Education: Notes on an Ongoing Debate. In:14th Annual IntEnt Conference. University of Napoli Federico II, Italy.

Alsos, G.A. and Kaikkonen, V. (2004), 'Opportunity recognition and prior knowledge: a study of experienced entrepreneurs', paper presented at 13th Nordic Conference on Small Business Research, Tromsø (Norway),10-12 June.

Athayde, R. (2009). Measuring Enterprise Potential in Young People. Entrepreneurship Theory and Practice, 33: 481-500.

Bandura, A. (1977). Social learning theory. Englewood Cliffs, NJ: Prentice-Hall.

Bandura, A. (1982). Self-efficacy mechanism in human agency. American Psychologist, 37, 122-147.

Bird B., (1988), "Implementing Entrepreneurial Ideas: The Case for Intention", Academy of Management Review, 13(3): 442-453.

DeTienne, D. R., \& Chandler, G. N. (2004). Opportunity Identification and Its Role in the Entrepreneurial Classroom: A Pedagogical Approach and Empirical Test. Academy of Management Learning \& Education, 3(3), 242-257.

Dohse, D., and Walter, S. (2010). The role of entrepreneurship education and regional context in forming entrepreneurial intentions. Working Papers 2010/18, Institut d'Economia de Barcelona (IEB). 
Fayolle, A., B. Gailly, et al. (2006). Effect and Counter-effect of Entrepreneurship Education and Social Context on Student's Intentions/Efectos de la formación y el contexto social sobre las intenciones empresariales de los estudiantes. Estudios de Economía Aplicada 24: 509-523.

Fayolle, A., Gailly, B., \& Lassas-Clerc, N. (2006). Assessing the impact of entrepreneurship education programmes: a new methodology. Journal of European Industrial Training, 30(9), 701-720.

Hills, G. E. (1995). Opportunity Recognition by Successful Entrepreneurs: A Pilot Study. In W. D. Bygrave, B. J. Bird, S. Birley, N. C. Churchill, M. Hay, R. H. Keeley, and W. E. Wetzel, Jr. (Eds.), Frontiers in Entrepreneurship Research 1995, pp.105-117, Wellesley, MA: Babson College.

Hills, G.E., Lumpkin, G. T. and Singh, R. P. (1997). Opportunity Recognition: Perceptions and Behaviors of Entrepreneurs. In P. D. Reynolds, W.D. Carter, P. Davidsson, W.B. Gartner, and P. McDougall (eds.) Frontiers in Entrepreneurship Research 1997, pp. 330-344, Wellesley, MA: Babson College.

Karimi, S., Chizari, M., Biemans, H. J. A., \& Mulder, M. (2010). Entrepreneurship Education in Iranian Higher Education: The Current State and Challenges. European Journal of Scientific Research, 48(1), 3550.

Karimi, S., Biemans H.J.A., Lans T., Chizari M. and Mulder M. (in press). The Impact of Entrepreneurship Education: A Study of Iranian Students' Entrepreneurial Intentions and Opportunity Identification. Journal of Small Business Management.

Karimi, S., H.J.A Biemans, T. Lans, , M. Mulder, and M. Chizari. (2012). The Role of Entrepreneurship Education in Developing Students' Entrepreneurial Intentions. Available at SSRN: http://ssrn.com/abstract=2152944

Karimi, S., H.J.A Biemans, T. Lans, M. Chizari, M. Mulder, and K. Naderi Mahdei. (2013). Understanding role models and gender influences on entrepreneurial intentions among college students. Procedia Social and Behavioral Sciences, forthcoming.

Kolvereid, L. (1996a). "Organizational employment versus self-employment: reasons for career choice intentions," Entrepreneurship Theory and Practice, 20(3), 23-31.

Kolvereid, L. (1996b). "Predictions of employment status choice intention,". Entrepreneurship Theory and Practice, 21 (1), 47-57.

Kourilsky M. (1995) "Entrepreneurship Education: Opportunity in Search of Curriculum", Centre for Entrepreneurial Leadership - Ewing Marion Kauffman Foundation, Missouri

Krueger NF, Carsrud AL (1993) Entrepreneurial intentions: Applying theory of planned behavior. Entrepreneurship and Regional Development 5: 315-330

Krueger, N. \& Brazeal, D. (1994). Entrepreneurial potential and potential entrepreneurs. Entrepreneurship Theory \& Practice, 19(2), 91-104.

Krueger, N. (1993). The impact of prior entrepreneurial exposure on perceptions of new venture feasibility and desirability. Entrepreneurship: Theory and Practice, 18(3l): 5-21.

Liñán, F., Rodríguez-Cohard, J. C., \& Rueda-Cantuche, J. M. (2011). Factors affecting entrepreneurial intention levels: a role for education. International Entrepreneurship and Management Journal, 7(2), 195218. 
McCline, R.L., Bhat, S., \& Baj, P. (2000). Opportunity recognition: An exploratory investigation of a component of the entrepreneurial process in the context of the healthcare industry. Entrepreneurship Theory and Practice, Winter, 81-94.

McNally, J. J., Martin, B. C., \& Kay, M. J. (2010, August). Examining the formation of human capital in entrepreneurship: A meta-analysis of entrepreneurship education outcomes. Paper presented at the Annual Meeting of the Academy of Management. Montreal, Canada

Munoz, C, C. A., Mosey, S., \& Binks, M. (2011). Developing opportunity identification capabilities in the classroom: Visual Evidance for Changing Mental Frames. Academy of Management Learning and Education 10(2), 277-295.

Nicolaou, N., Shane, S., Cherkas, L., \& Spector, T. D. (2009). Opportunity recognition and the tendency to be an entrepreneur: A bivariate genetics perspective. Organizational Behavior and Human Decision Processes, 110(2), 108-117. doi: 10.1016/j.obhdp.2009.08.005

Nixdorff, J., \& Solomon, G. (2007). Role of opportunity recognition in teaching entrepreneurship. March 22-24, NCIIA, 11th Annual Meeting, Tampa, FL

Ozgen, E., \& Baron, R. A. (2007). Social sources of information in opportunity recognition: Effects of mentors, industry networks, and professional forums. Journal of Business Venturing, 22(2), 174-192. doi: 10.1016/j.jbusvent.2005.12.001

Peterman, N. E. \& Kennedy, J. (2003). Enterprise education: Influencing students' perceptions of entrepreneurship. Entrepreneurship-Theory and Practice, 28(2): 129-144

Pittaway, L. \& Cope, J. (2007) Entrepreneurship Education - A Systematic Review of the Evidence. International Small Business Journal 25:5, 477-506.

Saks, N. T., \& Gaglio, C. M. 2002. Can opportunity identification be taught? Journal of Enterprising Culture, 10(4): 313-347

Shepherd, D., \& DeTienne, D. 2005. Prior knowledge, potential financial reward, and opportunity identification. Entrepreneurship Theory \& Practice, 29(1): 91-112.

Singh, R. P., Hills, G. E., Hybels, R. C., \& Lumpkin, G. T. 1999. Opportunity recognition through social network characteristics of entrepreneurs. In P. D. Reynolds, W. D. Bygrave, S. Manigart, C. M. Mason, G. D. Meyer, H. J. Sapienza, \& K. G. Shaver (Eds.), Frontiers of entrepreneurship research: 228- 256. Wellesley, MA: Babson College

Souitaris, V., Zerbinati, S., \& Al-Laham, A. (2007). Do entrepreneurship programs raise entrepreneurial intention of science and engineering students? The effect of learning, inspiration and resources. Journal of Business Venturing, 22(4), 566-591.

Ucbasaran, D., Westhead, P., Wright, M., \& Binks, M. (2003). "Does entrepreneurial experience influence opportunity identification," The Journal of Private Equity, 7(1), 7-14. doi: 10.3905/jpe.2003.320059

von Graevenitz, G., Harhoff, D., \& Weber, R. (2010). The effects of entrepreneurship education. Journal of Economic Behavior \& Organization, 76(1), 90-112. doi: 10.1016/j.jebo.2010.02.015

Weber, R. (2012). Theoretical Foundations. Evaluating Entrepreneurship Education (pp. 33-78): Gabler Verlag. 